Didaktik : Jurnal Pendidikan Guru Sekolah Dasar, ISSN : 24775673

Sekolah Tinggi Keguruan dan IImu Pendidikan Subang Volume II Nomor 2, Juli 2017

\title{
MENINGKATKAN AKTIVITAS DAN HASIL BELAJAR SISWA KELAS IX \\ PADA MATA PELAJARAN SEJARAH KEBUDAYAAN ISLAM (SKI) \\ MELALUI PENERAPAN MODEL PEMBELAJARAN \\ TIME TOKEN ARENDS DI MTS YAPITA TAMBUSAI \\ KABUPATEN ROKAN HULU
}

\author{
Bashori \\ Dosen STAI Tuanku Tambusai Pasir Pengaraian, Riau \\ bashoribashori@gmail.com
}

\begin{abstract}
This research is motivated by the low activity and learning outcomes of students of class IX in the subject Cultural History of Islam in MTs PP. YAPITA Tambusai Rokan Hulu. The purpose of this research is to know the implementation of learning model Time Token Arends for learning of Islamic culture history (SKI). The kind of this research is Classroom Action Research (PTK). Subjects in this study were students of class IX amounting to 24 people consisting of 14 male students and 10 female students. Collecting data in this study using observation and achievement test. After the data collected then analyzed using descriptive analysis techniques of qualitative and quantitative. As for the study hypothesis test using the test the test " $t$ ". The result showed that the application of learning models Time Token Arends can increase the activity and learning outcomes of students of class IX. Activities students of class IX has increased from $53.13 \%$ at $71.88 \%$ before the action became the first cycle and eventually reach $87.50 \%$ in the second cycle. While the average class IX student learning outcomes has increased from 65.83 at 72.08 before the action became the first cycle and finally reaching 80.63 in the second cycle. Likewise, completeness class (classical) experienced an increase of $37.50 \%$ on the prior actions, became $70.83 \%$ in the first cycle and eventually reach $100 \%$ in the second cycle.
\end{abstract}

Keywords: Learning Result, Islamic Culture History (SKI), Time Token Arend

\section{ABSTRAK}

Penelitian ini dilatarbelakangi oleh rendahnya aktivitas dan hasil belajar siswa kelas IX pada mata pelajaran Sejarah Kebudayaan Islam di MTs PP. YAPITA Tambusai Kabupaten Rokan Hulu. Tujuan penelitian ini yaitu untuk mengetahui penerapan model pembelajaran Time Token Arends pada mata pelajaran Sejarah Kebudayaan Islam (SKI). Metode penelitian ini adalah penelitian tindakan kelas (PTK). Subjek dalam penelitian ini adalah siswa kelas IX yang berjumlah 24 orang yang terdiri dari 14 orang siswa laki-laki dan 10 orang siswa perempuan. Pengumpulan data dalam penelitian ini menggunakan teknik observasi dan tes hasil belajar. Setelah data terkumpul selanjutnya dianalisis dengan menggunakan teknik analisis deskriptif kualitatif dan kuantitatif. Hasil analisis data menunjukkan bahwa penerapan model pembelajaran Time Token Arends dapat meningkatkan aktivitas dan 
hasil belajar siswa kelas IX. Aktivitas belajar siswa kelas IX mengalami peningkatan dari $53,13 \%$ pada sebelum tindakan menjadi $71,88 \%$ pada siklus I dan akhirnya mencapai $87,50 \%$ pada siklus II. Sementara rata-rata hasil belajar siswa kelas IX mengalami peningkatan dari 65,83 pada sebelum tindakan menjadi 72,08 pada siklus I dan akhirnya mencapai 80,63 pada siklus II. Demikian juga dengan ketuntasan kelas (klasikal) mengalami peningkatan dari $37,50 \%$ pada sebelum tindakan, menjadi $70,83 \%$ pada siklus I dan akhirnya mencapai $100 \%$ pada siklus II.

Kata Kunci: Hasil Belajar, Sejarah Kebudayaan Islam (SKI), Time Token Arend

\section{A. PENDAHULUAN}

Memasuki abad ke-21 sistem pendidikan nasional dihadapkan pada tantangan yang sangkat kompleks dalam menyiapkan sumber daya manusia yang mampu bersaing di era globalisasi. Melihat berbagai tantangan dan kecenderungan-kecenderungan

yang dihadapi dunia pendidikan, maka pemerintah telah mengoperasionalkan berbagai kebijakan dan regulasi guna peningkatan mutu pendidikan. Di antara kebijakan dan regulasi tersebut adalah keluarnya UU No. 20 Tahun 2003 tentang Sistem Pendidkan Nasional, Peraturan Pemerintah No. 19 Tahun 2005 tentang Standar Pendidikan Nasional, dan perubahan kurikulum pendidikan nasional.

Beberapa kebijakan dan regulasi di atas merupakan bentuk respon atas berbagai perubahan situasi dan kondisi zaman yang sangat cepat sehingga mempengaruhi berbagai aspek kehidupan, termasuk pendidikan nasional. Kunandar memandang bahwa beberapa pemicu perubahan dalam lingkungan pendidikan dapat diidentifikasi di antaranya seperti etos kerja tenaga kependidikan yang masih rendah sehingga menghambat percepatan penguasaan kompetensi yang dibutuhkan sesuai dengan perkembangan zaman. Selain itu juga prestasi belajar siswa tergolong masih rendah dengan indikator nilai UN dan kemampuan masuk perguruan tinggi masih rendah (Kunandar, 2008).

Menurut Wina Sanjaya bahwa salah satu masalah yang dihadapi pendidikan nasional 
adalah masalah lemahnya proses pembelajaran, dimana anak kurang didorong untuk mengembangkan kemampuan berfikir, tetapi diarahkan kepada kemampuan anak untuk menghafal, mengingat dan menimbun berbagai informasi tanpa dituntut untuk menghubungkannya dengan kehidupan sehari-hari (Sanjaya, 2010). Begitu juga dengan Trianto yang menyatakan bahwa masalah utama pembelajaran pada pendidikan formal dewasa ini adalah masih rendahnya daya serap siswa. Hal ini tampak dari rerata hasil belajar siswa yang senantiasa masih sangat memprihatinkan sebagai akibat dari kondisi pembelajaran yang masih bersifat konvensional dan tidak menyentuh ranah dimensi siswa itu sendiri, yaitu bagaimana sebenarnya belajar itu (Trianto, 2010)

Melihat realitas di atas diperlukan perubahan paradigma dalam pengelolaan pendidikan nasional dan praktik pendidikan di sekolah-sekolah agar sesuai dengan perkembangan dan tuntutan zaman. Menghadapi era globalisasi yang penuh persaingan dan ketidakpastian dibutuhkan guru yang visioner dan mampu mengelola proses pembelajaran secara efektif, inovatif dalam suasana yang menyenangkan dan bermakna. Hal ini dianggap wajar karena salah satu faktor utama yang menentukan mutu pendidikan adalah guru. Gurulah yang berada di garda terdepan dalam menciptakan kualitas sumber daya manusia, baik secara akademis, skill (keahlian), kematangan emosional, dan moral serta spiritual.

Salah satu upaya yang bisa dilakukan oleh guru untuk menciptakan pembelajaran yang efektif adalah dengan mempedomani standar proses pendidikan. Menurut PP No. 19 Tahun 2005 Bab I Pasal I Ayat 6 disebutkan bahwa standar proses adalah standar nasional pendidikan yang berkaitan dengan pelaksanaan pembelajaran pada satu satuan pendidikan untuk mencapai standar kompetensi lulusan. Penetapan standar proses pendidikan tersebut merupakan 
kebijakan yang sangat penting dan strategi untuk pemerataan dan peningkatan kualitas pendidikan. Melalui standar proses pendidikan setiap guru dapat menentukan bagaimana seharusnya proses pembelajaran dilaksanakan.

Pada jalur pendidikan formal, para siswa di MTs mempelajari berbagai macam materi Pendidikan Agama Islam, di mana salah satunya adalah Sejarah Kebudayaan Islam (SKI). Mata pelajaran Sejarah Kebudayaan Islam ini tidak kalah pentingnya dengan mata pelajaran Pendidikan Agama Islam lainnya. Sebagai bagian dari Pendidikan Agama Islam, mata pelajaran SKI mengajarkan kepada siswa untuk memahami nilai-nilai luhur agamanya. Oleh sebab itu, dalam pembelajarannya diarahkan untuk menyiapkan peserta didik agar dapat mengenal, memahami, menghayati sejarah kebudayaan Islam, yang kemudian menjadi dasar pandangan hidupnya (way of life) melalui kegiatan bimbingan, pengajaran, latihan, penggunaan pengataman dan pembiasaan.
Menurut Peraturan Menteri Agama RI No. 2 Tahun 2008 disebutkan bahwa Sejarah Kebudayaan Islam merupakan salah satu mata pelajaran yang menelaah tentang asal-usul, perkembangan, peranan kebudayaan/ peradaban Islam dan para tokoh yang berprestasi dalam sejarah Islam di masa lampau, mulai dari perkembangan masyarakat Islam pada masa Nabi Muhammad SAW dan Khulafaurrasyidin, Bani ummayah, Abbasiyah, Ayyubiyah sampai perkembangan Islam di Indonesia. Secara substansi, mata pelajaran Sejarah Kebudayaan Islam memiliki kontribusi dalam memberikan motivasi kepada peserta didik untuk mengenal, memahami, menghayati sejarah kebudayaan Islam, yang mengandung nilai-nilai kearifan yang dapat digunakan untuk melatih kecerdasan, membentuk sikap, watak, dan kepribadian peserta didik.

Salah satu materi SKI yang dipelajari oleh siswa kelas IX di MTs. PP. YAPITA Tambusai adalah tentang sejarah masuknya 
Islam di Indonesia. Pemberian materi ini diharapkan dapat meningkatkan pengenalan dan kemampuan mengambil ibrah terhadap peristiwa penting proses masuknya Islam serta dapat mewujudkan karakter siswa dalam mengapresiasi fakta dan makna serta dapat mengaitkannya dengan fenomena kehidupan sehari-hari.

Penyajian materi sejarah masuknya Islam ke Indonesia di kelas IX, guru menggunakan metode yang bervariasi, seperti ceramah, tanya jawab, dan penugasan. Harapan guru dengan menggunakan metode tersebut, para siswa dapat aktif dalam belajarnya sehingga dapat meningkatkan pemahaman mereka. Akan tetapi upaya guru tersebut di atas, masih jauh dari harapan, dimana sebagian besar siswa masih mengalami kesulitan dalam memahami materi. Kesulitan siswa inilah yang kemudian membuat pembelajaran SKI menjadi kurang optimal.

Kesulitan siswa kelas IX tersebut bukannya tanpa alasan, karena mata pelajaran SKI banyak mempelajari tentang fakta sejarah, seperti tempat dan waktu kejadian peristiwa, nama tokoh serta buktibukti sejarah lainnya. Di samping itu, mata pelajaran tersebut diajarkan pada jam-jam terakhir dengan penggunaan metode yang cenderung berpusat kepada guru dan hanya mengandalkan buku teks saja. Pendekatan pembelajaran seperti ini hanya akan membuat siswa menjadi pasif, sehingga mengakibatkan banyak siswa kelas IX yang menganggap bahwa materi tersebut kurang menarik dan menantang, bahkan siswa cepat merasa jenuh.

Sementara dilihat dari segi pencapaian hasil belajar Sejarah Kebudayaan Islam pada materi sejarah masuknya Islam di Indonesia tergolong masih rendah. Hal ini dapat dilihat dari dokumentasi nilai ulangan harian siswa kelas IX dimana dari 24 orang siswa yang memperoleh nilai sesuai KKM sebesar 70 hanya 9 orang $(37,50 \%)$, sementara 15 orang $(62,50 \%)$ siswa memperoleh nilai di bawah KKM. 
Melihat gejala-gejala tersebut di atas, mengindikasikan bahwa pembelajaran

Sejarah Kebudayaan Islam pada materi sejarah masuknya Islam di Indonesia masih mengalami kendala. Penulis menduga bahwa kendala-kendala tersebut diakibatkan karena belum diterapkannya model pembelajaran yang dapat meningkatkan aktivitas dan hasil belajar siswa. Oleh sebab itu, sebagai upaya memperbaiki kualitas proses dan hasil belajar Sejarah Kebudayaan Islam siswa kelas IX perlu diterapkan model pembelajaran yang berbasis aktivitas. Salah satu model pembelajaran yang ditawarkan dalam penelitian ini adalah time token arends.

Model pembelajaran time token itu sendiri berasal dari kata "time" artinya waktu dan "token" artinya tanda (Anwar, 2004, hlm. 38). Menurut Arends, time token adalah struktur yang dapat digunakan untuk mengajarkan ketrampilan sosial dan berpartisipasi agar menghindari siswa mendominasi pembicaraan atau siswa diam sama sekali
(Richard I Arend, 2008 : 30). Model pembelajaran time token arends merupakan salah satu model yang menempatkan siswa sebagai subyek (student centred). Dengan kata lain, siswa selalu dilibatkan secara aktif, sementara guru berperan untuk mengajak siswa mencari solusi bersama terhadap permasalahan yang ditemui. Sebagai upaya memperbaiki peningkatan kualitas pembelajaran dan hasil belajar siswa kelas IX pada mata pelajaran Sejarah Kebudayaan Islam, maka penulis merasa tertarik untuk mengadakan penelitian dengan judul: "Meningkatkan Aktivitas dan Hasil Belajar Siswa Kelas IX Pada Mata Pelajaran Sejarah Kebudayaan Islam Melalui Penerapan Model Pembelajaran Time Token Arends dl MTs. PP. YAPITA Tambusai Kabupaten Rokan Hulu".

\section{B. LANDASAN TEORI}

\section{Aktivitas Belajar}

\section{a. Pengertian Aktivitas Belajar}

Memahami aktivitas belajar dapat dilihat dari kata-kata yang membentuknya, yaitu aktivitas dan 
belajar. Aktivitas menurut Kamus Besar Bahasa Indonesia (KBBI) artinya adalah kegiatan, kesibukan. yang dengan mengarahkan seluruh tenaga, pikiran atau badan untuk mencapai suatu tujuan (KBBI, 2005 : 30). Menurut Sardiman, aktivitas adalah kegiatan yang melibatkan fisik dan mental (AM. Sardiman, 2008, hlm. 100).

Menurut Rohani, aktivitas fisik ditandai dengan kegiatan seperti aktif dengan anggota badan, membuat sesuatu, bermain atau bekerja, tidak hanya duduk dan mendengarkan, melihat atau hanya pasif. Sedangkan aktivitas mental ditandai dengan kegiatan seperti mengamati dengan teliti, memecahkan persoalan, dan mengambil keputusan (Rohani, 2008, hlm. 6-7). Sementara belajar dalam Kamus Besar Bahasa Indonesia berarti berusaha memperoleh kepandaian atau ilmu, berlatih serta berubah tingkah laku atau tanggapan yang disebabkan oleh pengalaman (KKBI, 2005 : 17).

Menurut Ali belajar adalah proses perubahan tingkah laku akibat interaksi dengan lingkungan (Ali, 2008 : 14). Sedangkan Trianto menjelaskan bahwa belajar diartikan sebagai proses perubahan perilaku tetap dari belum tahu menjadi tahu, dari tidak paham menjadi paham, dari kurang terampil menjadi terampil, dari kebiasaan lama menjadi kebiasaan baru, serta bermanfaat bagi lingkungan maupun individu itu sendiri (Trianto, $2011: 17$ ).

Budiningsih mengartikan belajar dengan perubahan tingkah laku sebagai akibat dari adanya interaksi antara stimulus dan respon. Dengan kata lain, belajar merupakan bentuk perubahan yang dialami siswa dalam hal kemampuannya untu bertingkah laku dengan cara yang baru sebagai hasil interaksi antara stimulus dan respon (Budiningsih, 2005 : 20). Sedangkan menurut Dimyati dan Mudjiono bahwa belajar adalah kegiatan individu untuk memperoleh pengetahuan, perilaku dan keterampilan dengan cara mengolah bahan belajar (Dimyati, 2006 : 295).

Berdasarkan pengertian aktivitas dan belajar seperti yang 
diuraikan di atas, maka dapat diambil kesimpulan bahwa yang dimaksud dengan aktivitas belajar adalah kegiatan yang dilakukan siswa dengan melibatkan fisik dan mental siswa selama proses pembelajaran dalam rangka memperoleh perubahan baik dari segi pengetahuan, sikap, maupun keterampilan. Jika siswa sudah terlibat secara fisik dan mental, maka siswa akan merasakan suasana belajar yang lebih menyenangkan sehingga hasil belajar dapat dimaksimalkan. Hal ini sesuai dengan pendapat Kunandar yang menyatakan bahwa aktivitas belajar adalah keterlibatan siswa dalam bentuk sikap, pikiran, perhatian guna menunjang keberhasilan proses belajar mengajar dan memperoleh manfaat dari kegiatan tersebut (Kunandar, 2007 : 277).

\section{b. Jenis-jenis Aktivitas Belajar}

\section{Siswa}

Menurut Sardiman dalam bukunya menjelaskan bahwa ada beberapa teori tentang aktivitas belajar yaitu: a) Visual activities: membaca, memperhatikan: gambar, demonstrasi, percobaan, pekerjaan orang lain dan sebagainya;

b) Oral activities: menyatakan, merumuskan, bertanya, memberi saran, mengeluarkan pendapat, mengadakan interview, diskusi, interupsi dan sebagainya; c) Listening activities: mendengarkan uraian, percakapan diskusi, musik, pidato dan sebagainya; d) Writing activities: menulis cerita, karangan, laporan, angket, test, menyalin dan sebagainya; e) Drawing activities: menggambar, membuat grafik, peta, diagram, pola dan sebagainya; f) Motor activities: melakukan percobaan, membuat konstruksi, model, mereparasi, bermain, berkebun, memelihara binatang dan sebagainya; g) Mental activities: menganggap, mengingat, memecahkan masalah, menganalisis, melihat hubungan, mengambil keputusan dan sebagainya; dan $h$ ) Emotional activities: menaruh minat, merasa bosan, gembira, berani, tenang, gugup dan sebagainya (AM. Sardiman, 2010 : 
101).

Berdasarkan teori yang dikemukakan oleh Sardiman di atas, maka dapat diketahui bahwa aktivitas belajar siswa tercermin dari kegiatan siswa menggunakan fisik maupun psikisnya. Kegiatan fisik meliputi aktivitas penglihatan, pengucapan, pendengaran, menulis, menggambar, membaca, memperhatikan, menggambar, mendemonstrasikan, dan gerak. Sementara kegiatan psikis meliputi aktivitas mental dan emosional siswa.

\section{Hasil Belajar}

\section{a. Pengertian Hasil Belajar}

Menurut Purwanto, hasil belajar dapat dijelaskan dengan memahami dua kata yang membentuknya, yaitu "hasil" dan "belajar". Hasil (product) merujuk pada perolehan akibat dilakukannya suatu aktivitas atas proses yang mengakibatkan berubahnya input secara fungsional. Sementara belajar merupakan upaya mengubah perilaku pada individu yang belajar (Purwanto, 2013 : 45). Dari pendapat tersebut, maka hasil belajar diartikan dengan perubahan yang mengakibatkan manusia berubah, baik dalam sikap dan tingkah lakunya.

Menurut Kamus Besar Bahasa Indonesia, hasil belajar diartikan dengan penguasaan pengetahuan atau keterampilan yang dikembangkan oleh mata pelajaran, lazimnya ditujukan dengan nilai tes atau angka yang diberikan oleh guru (KBBI, 2005 : 895). Pengertian hasil belajar yang senada juga diungkapkan oleh Sudjana yang menyatakan bahwa hasil belajar adalah kemampuankemampuan yang dimiliki peserta didik setelah menerima pengalaman belajarnya (Sudjana, 2002 : 22). sementara menurut Abdurrahman, hasil belajar adalah kemampuan yang diperoleh anak setelah melalui kegiatan belajar (Abdurrahman, 1999 : 37).

Dari beberapa pendapat di atas maka dapat disimpulkan bahwa hasil belajar adalah bentukbentuk kemampuan yang dimiliki siswa setelah melalui tahapan pembelajaran yang ditunjukkan dengan nilai yang diberikan oleh guru. Bentuk-bentuk kemampuan 
tersebut meliputi kognitif, afektif maupun psikomotorik.

\section{b. Tipe-tipe Hasil Belajar}

Menurut Trianto, hasil belajar dapat diindikasikan dalam berbagai bentuk seperti perubahan pengetahuan, pemahaman, sikap dan tingkah laku, kecakapan, keterampilan dan kemampuan serta perubahan aspek-aspek yang lain yang ada pada individu yang belajar (Trianto, 2010 : 9). Sementara itu Suprijono menyebutkan bahwa hasil belajar berupa: a) Informasi verbal yaitu kapabilitas mengungkapkan pengetahuan dalam bentuk bahasa, baik lisan maupun tertulis; b) Keterampilan intelektual yaitu kemampuan mempresentasikan konsep dan lambing; c) Strategi kognitif yaitu kecakapan menyalurkan dan mengarahkan aktivitasnya sendiri (penggunaan konsep dan memecahkan masalah); d) Keterampilan motorik yaitu kemampuan melakukan serangkaian gerak jasmani dalam urusan dan koordinasi, sehingga terwujud otomatisme gerak jasmani; e) Sikap adalah kemampuan menerima atau menolak objek berdasarkan penilaian terhadap objek tersebut (Suprijono, 2013: 6).

Menurut taksonomi yang dikemukakan oleh Bloom seperti yang kutip oleh Purwanto bahwa hasil belajar mencakup tiga ranah yaitu: kognitif, afektif, dan psikomotor. Ranah kognitif adalah ranah yang mencakup kegiatan mental (otak). Segala upaya yang menyangkut aktivitas otak adalah termasuk dalam ranah kognitif. Dalam ranah kognitif itu terdapat enam jenjang proses berpikir yaitu pengetahuan (knowledge), pemahaman (comprehension), penerapan (application), analisis (analysis), sintesis (synthesis), dan penilaian (evaluation).

Selanjutnya, ranah afektif adalah ranah yang berkaitan dengan sikap dan nilai. Ranah afektif dibagi menjadi lima jenjang, yaitu: receiving atau attending (menerima atau memperhatikan), responding (menanggapi), valuing (menilai), organization (mengatur atau mengorganisasikan), characterization by a value or value complex (karakterisasi 
dengan suatu nilai atau komplek nilai).

Kemudian Ranah psikomotor adalah ranah yang berkaitan dengan keterampilan (skill) atau kemampuan bertindak setelah seseorang menerima pengalaman belajar tertentu yang memiliki enam tingkatan yaitu: persepsi (perception), kesiapan (set), gerakan terbimbing (guided response), gerakan terbiasa (mechanism), gerakan kompleks (adaptation), dan gerakan kreativitas (origination) (Purwanto, 2004 : 51-53).

Merujuk pada beberapa pendapat di atas, maka dapat disimpulkan bahwa hasil belajar merupakan perubahan tingkah laku setelah mengikuti pembelajaran yang dapat dilihat melalui tiga ranah yaitu kognitif, afektif maupun psikomotorik.

\section{c. Faktor-faktor} yang

\section{Mempengaruhi Hasil Belajar}

Menurut Sudjana, hasil belajar yang dicapai siswa dipengaruhi oleh dua faktor utama, yakni faktor yang berasal dari dalam diri siswa dan faktor yang berasal dari luar diri siswa. Faktor yang datang dari diri siswa meliputi kemampuan yang dimiliki, motivasi, minat dan perhatian, sikap dan kebiasaan belajar, ketekunan, sosial ekonomi, faktor fisik dan psikis. Sedangkan faktor yang berasal dari luar diri siswa adalah kualitas pengajaran, yaitu tinggi rendahnya atau efektif tidaknya pembelajaran yang dilakukan guru dalam mencapai tujuan pengajaran (Sudjana, 2002 : $39-40)$.

Menurut Purwanto faktorfaktor yang mempengaruhi hasil belajar siswa terdiri dari dua faktor yaitu faktor internal dan faktor eksternal. Adapun yang termasuk faktor internal meliputi kondisi fisik, kondisi panca indera, bakat, minat, kecerdasan, motivasi, dan kemampuan kognitif. Sedangkan yang termasuk faktor eksternal meliputi kondisi alam, kondisi sosial, kurikulum, bahan pelajaran, guru, sarana dan prasarana serta adminsitrasi atau manajemen (Purwanto, 2013 : 39).

Begitu juga dengan Syah yang menyatakan bahwa secara umum faktor-faktor yang 
mempengaruhi hasil belajar antara lain:

1) Faktor internal yang berasal dari dalam diri siswa meliputi dua aspek yaitu: a) aspek fisiologis (yang bersifat jasmaniah) seperti kondisi jasmani dan tegangan otot serta tingkat kebugaran organ-organ tubuh dan sendi-sendinya, dapat mempengaruhi semangat dan intensitas siswa dalam mengikuti pelajaran, b) aspek psikologis (yang bersifat rohaniah) seperti intelegensi atau tingkat kecerdasan, sikap, bakat, minat, dan motivasi siswa.

2) Faktor eksternal yang berasal dari luar diri siswa terdiri atas dua macam yaitu: a) lingkungan sosial seperti para guru, para staf administrasi, dan temanteman sekelas, masyarakat, tetangga, dan teman sepermainan di sekitar perkampungan siswa, b) lingkungan non sosial seperti gedung sekolah, rumah, alat alat-alat belajar, keadaan cuaca, dan waktu belajar yang digunakan siswa.
Faktor pendekatan belajar yaitu jenis upaya belajar siswa yang meliputi strategi dan metode yang digunakan siswa untuk melakukan kegiatan mempelajari materi-materi pelajaran (Syah, $2008: 195)$

\section{Model Pembelajaran Time} Token Arends

a. Pengertian

Model

Pembelajaran Time Token

\section{Arends}

Sebelum diuraikan tentang model pembelajaran time token arends, maka perlu dijelaskan terlebih dahulu pengertian model pembelajaran. Menurut Suprijono, model pembelajaran adalah pola yang digunakan sebagai pedoman dalam merencanakan pembelajaran di kelompok maupun tutorial. (Suprijono, 2013 : 46). Sedangkan menurut Syaiful Sagala, model pembelajaran adalah kerangka konseptual yang menggambarkan prosedur yang sistematis dalam mengorganisasisasikan pengalaman belajar peserta didik untuk mencapai tujuan belajar tertentu, dan berfungsi sebagai pedoman bagi perancang 
pembelajaran dan guru dalam merencanakan dan melaksanakan aktivitas belajar mengajar (Sagala, 2010 : 175).

Menurut Joyce \& Weil yang dikutip oleh Rusman berpendapat bahwa model pembelajaran adalah suatu rencana atau pola yang dapat digunakan untuk membentuk kuikulum, merancang bahanbahan pembelajaran, dan membimbing pembelajaran di kelas atau yang lainnya. Dengan model pembelajaran tersebut dapat dijadikan pilihan, artinya para guru boleh memilih model pembelajaran yangb sesuai dan efesien untuk mencapai tujuan pendidikannya (Rusman, 2012 : 133).

\section{Berdasarkan}

beberapa pendapat di atas, maka dapat disimpulkan bahwa model pembelajaran merupakan suatu kerangka acuan yang digunakan guru dalam pembelajaran untuk mencapai tujuan tertentu. Artinya, model pembelajaran digunakan oleh guru sebagai pedoman dalam melaksanakan pembelajaran di kelas.
Model pembelajaran time token arends diambil dari nama penemunya yaitu Richard I Arends. Model ini pertama kali diperkenalkan oleh Arends pada tahun 1998. Dari namanya, model pembelajaran time token sendiri terdiri dari dua kata, yaitu "time" dan "token". Menurut kamus Bahasa Inggris, "time" artinya waktu (Anwar, 2004), sedangkan "token" artinya tanda. Merujuk pada arti kata tersebut, maka time token merupakan model pembelajaran yang memiliki ciri tanda waktu atau batasan waktu. Batasan waktu disini bertujuan untuk memacu dan memotivasi siswa agar aktif dalam berbicara atau mengemukakan pemikiran, ide, maupun gagasannya.

Menurut Arends dalam Prajitno Soetjipto dan Sri Mulyantini Soetjipto, time token adalah struktur yang dapat digunakan untuk mengajarkan ketrampilan sosial dan berpartisipasi agar menghindari siswa mendominasi pembicaraan atau siswa diam sama sekali (Arends, 2008 : 30). Pendapat lainnya seperti yang diungkapkan 
oleh Alviandri, bahwa time token arends adalah model pembelajaran kooperatif yang menuntut partisipasi siswa dalam kelompok untuk berbicara (mengeluarkan ide/gagasannya) dengan diberi kupon berbicara sehingga semua siswa harus berbicara. Maka dari itu, siswa tidak ada yang mendominasi dalam pelaksanaan diskusi (Alpiandi, 2015).

Berdasarkan pendapatpendapat di atas, maka dapat dipahami bahwa model pembelajaran time token merupakan model pembelajaran yang digunakan untuk mengembangkan kemampuan siswa dalam mengeluarkan ide, pendapat, maupun gagasannya terhadap masalah-masalah yang diajukan. Dengan adanya model pembelajaran time token ini, maka siswa yang tadinya hanya diam dalam mengikuti pembelajaran terlibat secara aktif melalui kegiatan bertanya, menjawab pertanyaan, maupun memberi tanggapan. b. Langkah-langkah Model Pembelajaran Time Token Arends

Langkah-langkah model pembelajaran time token arends adalah sebagai berikut: a) Kondisikan kelas untuk melaksanakan diskusi; b) Tiap siswa diberi kupon berbicara dengan waktu \pm 30 detik; c) Bila telah selesai bicara kupon yang dipegang siswa diserahkan. Setiap berbicara satu kupon; d) Siswa yang telah habis kuponnya tak boleh bicara lagi, sementara yang masih pegang kupon harus bicara sampai kuponnya habis; dan seterusnya (Suprijono, 2013 : 133). c. Kelebihan dan Kelemahan Model Pembelajaran Time Token Arends

Pada dasarnya setiap model pembelajaran mempunyai kelebihan dan juga kelemahan. Meskipun, ada kekurangan dalam model pembelajaran, sebisa mungkin seorang guru harus profesional dalam menjalankan tugasnya. Dengan demikian guru harus mampu memaksimalkan penggunaan model pembelajaran tersebut untuk mengajar dan 
meminimalisir kekurangan yang terjadi.

Time Token Arends merupakan salah satu dari berbagai model pembelajaran kooperatif. Sebagai bagian dari pembelajaran kooperatif, maka dalam implementasinya memiliki beberapa kelebihan dan kelemahan. Menurut Wina Sanjaya, beberapa kelebihan model pembelajaran kooperatif ini antara lain: a) Dapat menambah kemampuan berfikir sendiri, menemukan informasi dari berbagai sumber, dan belajar dari siswa lain; b) Dapat mengembangkan kemampuan mengungkapkan ide atau gagasan dengan kata-kata secara verbal dan membandingkannya dengan ide-ide orang lain; c) Dapat membantu siswa untuk respek pada orang lain dan menyadari akan segala keterbatasannya serta menerima segala perbedaan; d) Dapat membantu memberdayakan setiap siswa untuk lebih bertanggung jawab dalam belajar; e) Dapat meningkatkan prestasi akademik sekaligus kemampuan sosial, mengembangkan harga diri, hubungan interpersonal yang positif dengan yang lain, mengembangkan keterampilan mengatur waktu, dan sikap positif terhadap sekolah.

Sedangkan beberapa kelemahannya antara lain: a) Siswa yang memiliki kelebihan akan merasa terhambat oleh siswa yang dianggap kurang memiliki kemampuan. Akibatnya, keadaan semacam ini dapat mengganggu iklim kerja sama dalam kelompok; b) Jika tidak diiringi dengan peer teaching yang efektif, maka apa yang dipelajari dan dipahami siswa tidak pernah tercapai oleh siswa; c) Memerlukan waktu yang lama dalam menerapkan strategi ini; dan d) Penilaian yang diberikan cenderung didasarkan pada hasil kerja kelompok, padahal sebenarnya hasil yang diharapkan adalah prestasi setiap individu siswa (Sanjaya, 2011 : 33).

\section{METODE PENELITIAN}

Jenis penelitian ini adalah penelitian tindakan kelas (PTK). PTK digunakan oleh para guru guna melihat kualitas pembelajaran yang ada di dalam 
kelas secara komprehensif.

Adapun alokasi waktu dalam penelitian tindakan kelas ini membutuhkan waktu selama 2 bulan yaiyu terhitung mulai bulan Maret hingga bulan April 2016. Sedangkan lokasi penelitiannya adalah di MTs PP. YAPITA Tambusai Kabupaten Rokan Hulu. Teknik pengumpulan data yang penulis gunakan dalam penelitian ini adalah teknik observasi dan tes hasil belajar. dalam menganalisis data, penulis menggunakan dua analisis data yaitu yaitu data kualitatif dan kuantitatif. Data kualitatif dianalisis menggunakan teknik analisis deskriptif dengan persentase, sedangkan data yang bersifat kuantitatif disajikan dengan menggunakan uji statistik.

\section{PEMBAHASAN}

1. Aktivitas dan Hasil Belajar Siswa Kelas IX Sebelum Tindakan

a. Data aktivitas belajar siswa kelas IX sebelum tindakan

Dari hasil observasi diketahui bahwa aktivitas belajar siswa kelas IX sebelum tindakan dikategorikan kurang baik dengan jumlah skor sebesar 51dari skor maksimal sebesar 96 dengan persentase sebesar $53,13 \%$.

b. Data Hasil belajar siswa kelas IX sebelum tindakan

Diperoleh bahwa jumlah total nilai yang diperoleh siswa kelas IX sebesar 1580 dengan rata-rata sebesar 65,83. Rata-rata yang diperoleh tersebut masih di bawah KKM yang telah ditentukan yaitu 70. Dari 24 orang siswa kelas IX, yang dinyatakan tuntas sebanyak 9 orang, sedangkan yang belum tuntas sebanyak 15 orang dengan persentase ketuntasan kelas (klasikal) sebesar $37,50 \%$. Dilihat dari hasil yang diperoleh siswa kelas IX tersebut, maka perlu dilakukan upaya tindakan untuk meningkatkan aktivitas dan hasil belajar siswa kelas IX pada mata pelajaran Sejarah Kebudayaan Islam dengan menerapkan model pembelajaran Time Token Arends.

\section{Hasil Penelitian Tindakan}

\section{Kelas Siklus I}

Siklus I ini dilaksanakan pada tanggal 21 Maret 2016 dengan alokasi waktu setiap pertemuan $2 \mathrm{x}$ 40 menit. 
a. Hasil aktivitas siswa pada siklus 1

Berdasarkan hasil penelitian diperoleh hasil yang menunjukkan bahwa aktivitas belajar siswa kelas IX pada siklus I dikategorikan baik dengan perolehan skor sebesar 69 dari skor maksimal sebesar 96 dengan persentase sebesar $71,88 \%$.

b. Hasil belajar siswa kelas IX pada siklus I

Diperolah hasil menujukkan bahwa jumlah total nilai yang diperoleh dari 24 orang siswa kelas IX sebesar 1730 dengan rata-rata sebesar 72,08. Dari 24 orang siswa kelas IX, yang dinyatakan tuntas sebanyak 17 orang, sedangkan yang tidak tuntas sebanyak 7 orang.

Sementara ketuntasan kelas (klasikal) pada siklus I mencapai $70,83 \%$.

c. Refleksi

Berdasarkan hasil penelitian tindakan kelas pada siklus I, maka dapat penulis refleksikan sebagai berikut:

$\begin{array}{lll}\text { 1) Aktivitas } & \text { guru } & \text { dalam } \\ \text { pembelajaran } & \text { pada siklus । } \\ \text { dikategorikan } & \text { baik dengan }\end{array}$

persentase sebesar 70\%. Akan tetapi masih terdapat beberapa tahapan pembelajaran yang kurang dilaksanakan oleh guru di antaranya adalah sebagai berikut:

a) Guru kurang memeriksa kesiapan belajar siswa sebagai modal awal dalam mengikuti pembelajaran.

b) Guru kurang membimbing setiap kelompok siswa pada saat melakukan diskusi.

c) Guru kurang mengajak siswa dalam menyimpulkan materi sehingga pengetahuan yang didapat siswa selama mengikuti pembelajaran belum diketahui secara pasti.

2) Aktivitas belajar siswa kelas IX pada siklus I dikategorikan baik dengan persentase sebesar $71,88 \%$. Hal ini menunjukkan bahwa siswa kelas IX sudah mulai bisa beradaptasi dengan model pembelajaran Time Token Arends yang diterapkan guru. Akan tetapi masih ada beberapa siswa yang terlihat kurang aktif dalam diskusi dan kurang berani berbicara. 
3) Hasil belajar siswa kelas IX pada siklus I diperoleh jumlah total nilai sebesar 1730 dengan rata-rata sebesar 72,08dalam kategori tinggi. Jumlah siswa yang dinyatakan tuntas sebanyak 17 orang dan yang tidak tuntas sebanyak 7 orang dengan persentase ketuntasan kelas (klasikal) sebesar 70,83\%. Dari hasil yang diperoleh pada siklus I ini menunjukkan bahwa rata-rata hasil belajar siswa kelas IX mengalami peningkatan sebesar 6,25 dari sebelum tindakan yang hanya mencapai 65,83 menjadi 72,08 pada siklus I. Di samping itu jumlah siswa kelas IX yang dinyatakan tuntas juga mengalami peningkatan sebesar 33,33\% dari $37,50 \%$ pada sebelum tindakan menjadi $70,83 \%$ pada siklus I. Meskipun rata-rata hasil belajar siswa kelas IX sudah di atas KKM, akan tetapi ketuntasan kelas masih di bawah $85 \%$.

Berdasarkan hasil refleksi siklus I di atas, menunjukkan adanya keberhasilan maupun kelemahan yang telah diraih selama siklus I, baik dari aktivitas guru dalam pembelajaran, aktivitas belajar siswa, maupun hasil belajar siswa. Untuk memperbaiki kelemahan dan mempertahankan keberhasilan yang telah dicapai pada siklus I, maka perlu upaya tindakan pada siklus II dengan lebih memperhatikan hal-hal berikut ini:

1) Guru perlu memeriksa kembali kesiapan belajar siswa sebelum pembelajaran dimulai.

2) Guru perlu membimbing setiap kelompok siswa pada saat melakukan diskusi agar setiap kelompok siswa lebih aktif lagi dalam diskusi dan kelompok siswa yang mengalami kesulitan dapat terbantu.

3) Guru perlu melibatkan siswa dalam membuat kesimpulan agar dapat diketahui sejauh mana pemahaman siswa terhadap materi yang telah dipelajarinya.

\section{Hasil Penelitian Tindakan}

\section{Kelas Siklus II}

Pelaksanaan tindakan pada siklus II ini merupakan hasil refleksi siklus lyang dilaksanakan pada tanggal 28 Maret 2016 
dengan alokasi waktu selama $2 \mathrm{x}$ 40 menit.

a. Hasil observasi aktivitas guru

Berdasarkan hasil observasi menunjukkan bahwa aktivitas guru pada siklus II dikategorikan sangat baik dimana skor total yang diperoleh sebanyak 10 dari skor maksimal sebesar 10 dengan persentase sebesar $100 \%$.

b. Aktivitas belajar siswa kelas IX

Berdasarkan penelitian menunjukkan bahwa secara keseluruhan aktivitas belajar siswa kelas IX pada siklus II dikategorikan sangat baik dengan perolehan skor sebesar 84 dari skor maksimal sebesar 96 dengan persentase sebesar $87,50 \%$.

C. Hasil belajar siswa kelas IX

Berdasarkan hasil penelitian menujukkan bahwa jumlah total nilai yang diperoleh dari 24 orang siswa kelas IX sebesar 1935 dengan rata-rata sebesar 80,63. Pada siklus II ini seluruh siswa kelas IX dinyatakan tuntas seluruhnya dengan ketuntasan kelas sebesar $100 \%$.

d. Refleksi

Berdasarkan hasil penelitian tindakan kelas pada siklus II, maka dapat penulis refleksikan sebagai berikut:

1) Guru telah berusaha menerapkan model pembelajaran Time Token Arendsdengan lebih baik.

2) Aktivitas belajar kelompok siswa kelas IX telah sesuai dengan langkah-langkah model pembelajaran Time Token Arendssecara lebih baik.

3) Hasil belajar siswa kelas IX pada siklus II dikategorikan tinggi dengan perolehan ratarata sebesar 80,63. Hal ini menunjukkan adanya peningkatan sebesar 8,54 dari siklus I yang hanya mencapai 72,68. Ketuntasan kelaspada siklus II juga mengalami peningkatan sebesar 29,17\% dari siklus I yang hanya mencapai $70,83 \%$ menjadi $100 \%$ pada siklus II.

Dengan keberhasilankeberhasilan yang telah diraih pada siklus II baik dari segi aktivitas guru, aktivitas kelompok belajar siswa kelas IX serta hasil belajar siswa kelas IX, maka penulis tidak lagi mengadakan tindakan siklus III karena kriteria 
penelitian tindakan kelas ini telah terpenuhi seluruhnya, baik ratarata hasil belajar siswa kelas IX sudah melebihi KKM sebesar 70 maupun ketuntasan kelas yang melebihi $85 \%$.

\section{Analisis Data}

Setelah data-data hasil penelitian tindakan kelas disajikan, selanjutnya dilakukan analisis. Analisis data ini dilakukan untuk melihat peningkatanaktivitas belajar dan hasil belajar siswa kelas IX antara sebelum dan sesudah dilakukan tindakan.Adapun proses analisis data aktivitas dan hasil belajar siswa kelas IX adalah sebagai berikut:

\section{a. Analisis Data Aktivitas Belajar Siswa Kelas IX}

Berdasarkan hasil penelitian diketahui bahwa aktivitas belajar siswa kelas IX pada sebelaum tindakan dikategorikan kurang baik dimana jumlah skor total yang diperoleh sebesar 51 dari skor maksimal sebesar 96 dengan persentase sebesar 53,13\%. Pada siklus laktivitas belajar siswa kelas IX dikategorikan cukup baik dimana jumlah skor total yang diperoleh sebesar 69 dari skor maksimal sebesar 96 dengan persentase sebesar $71,88 \%$. Sementara pada siklus II aktivitas belajar siswa kelas IX dikategorikan sangat baik dimana jumlah skor total yang diperoleh sebesar 84 dari skor maksimal sebesar 96 dengan persentase sebesar 87,50\%. Melihat hasil analisis data tersebut maka dapat disimpulkan bahwa penerapan model pembelajaran TimeToken Arends dapat meningkatkan aktivitas belajar siswa kelas IX pada mata pelajaran Sejarah Kebudayaan Islam di MTs PP. YAPITA Tambusai Kabupaten Rokan Hulu.

\section{b. Analisis Hasil Belajar Siswa Kelas IX}

Dalam menganalisis peningkatan hasil belajar siswa kelas IX tersebut, penulis menggunakan rumus yang telah ditetapkan sebelumnya yaitu:

$$
\mathrm{M}=\frac{\sum X}{N}
$$

Berdasarkan hasil penelitian diketahui bahwa jumlah total nilai sebelum tindakan diperoleh sebesar 1580 dengan rata-rata 
sebesar 65,83 dalam kategori cukup tinggi dan ketuntasan kelas mencapai $\quad 37,50 \%$. Setelah dilakukan tindakan pada siklus I diperoleh jumlah total nilai 1730 dengan rata-rata sebesar 72,08 dalam kategori tinggi dan ketuntasan kelas telah mencapai 70,83\%. Setelah dilakukan tindakan pada siklus II diperoleh jumlah total nilai sebesar 1935 dengan rata-rata sebesar 80,63 dalam kategori sangat tinggi dan ketuntasan kelas mencapai $100 \%$.

Berdasarkan hasil analisis data yang telah diuraikan di atas menunjukkan bahwa hasil belajar siswa kelas IX dan persentase ketuntasan kelas mengalami peningkatan dari sebelum tindakan dan setelah dilakukan tindakan pada siklus I dan siklus II maupun persentase ketuntasan kelas. Rata-rata hasil belajar siswa kelas IX mengalami peningkatan dari 65,83pada sebelum tindakan menjadi 70,83 pada siklus I dan 80,63 pada siklus II. Sedangkan persentase ketuntasan kelas juga mengalami peningkatan dari $37,50 \%$ pada sebelum tindakan menjadi $70,83 \%$ pada siklus I dan 100\% pada siklus II.

\section{Uji Hipotesis}

Untuk menguji hipotesis yang telah dirumuskan sebelumnya, penulis menggunakan uji tes " $\mathrm{t}$ " dengan rumus sebagai berikut:

$$
t_{o}=\frac{\left(\frac{\sum D}{N}\right)}{\left(\frac{S D_{D}}{\sqrt{N-1}}\right)}
$$

Adapun proses uji hipotesisnya adalah sebagai berikut:

a. Aktivitas Belajar Siswa Kelas IX

1) Menghitung harga todengan menyiapkan tabel perhitungan untuk mencari $\sum D$ dan $\sum D^{2}$ diperoleh $\mathrm{N}=24$, $\sum D=-33, \sum D^{2}=55$.

2) Mencari standar deviasi perbedaan skor aktivitas belajar

$$
\begin{aligned}
S D_{D} & =\sqrt{\frac{\sum D^{2}}{N}}-\left(\frac{\sum D}{N}\right)^{2} \\
& =\sqrt{\frac{55}{24}-\left(\frac{-33}{24}\right)^{2}} \\
=\sqrt{2,292}- & (-1,375)^{2} \\
& =\sqrt{2,292-} 1,891 \\
& =\sqrt{0,401} \\
S D_{D} & =0,633
\end{aligned}
$$

3) Substitusikan ke dalam rumus mencari to 


$$
\begin{aligned}
t_{O} & =\frac{\left(\frac{\sum D}{N}\right)}{\left(\frac{S D_{D}}{\sqrt{N-1}}\right)} \\
& =\frac{\left(\frac{-33}{24}\right)}{\frac{0,633}{\sqrt{24-1}}} \\
& =\frac{-1,375}{\left(\frac{0,633}{\sqrt{23}}\right)} \\
& =\frac{-1,375}{\left(\frac{0,633}{4,796}\right)} \\
& =\frac{-1,375}{0,132} \\
t_{o} & =-10,42
\end{aligned}
$$

6. Hasil Belajar Siswa Kelas IX

a. Menghitung harga todengan menyiapkan tabel perhitungan untuk

mencari

$\sum D$ dan $\sum D^{2}$ diperoleh $\mathrm{N}=24$, $\sum D=-355, \sum D^{2}=5675$.

b. Mencari standar deviasi perbedaan skor

$$
\begin{aligned}
S D_{D} & =\sqrt{\frac{\sum D^{2}}{N}}-\left(\frac{\sum D}{N}\right)^{2} \\
& =\sqrt{\frac{5675}{24}}-\left(\frac{-355}{24}\right)^{2} \\
=\sqrt{236,458} & -(-14,79)^{2} \\
& =\sqrt{236,458-} \\
& 218,744 \\
& =\sqrt{17,714} \\
S D_{D} & =4,208
\end{aligned}
$$

C. Substitusikan ke dalam rumus mencari to

$$
\begin{aligned}
t_{O} & =\frac{\left(\frac{\sum D}{N}\right)}{\left(\frac{S D_{D}}{\sqrt{N-1}}\right)} \\
& =\frac{\left(\frac{-355}{24}\right)}{\frac{4,208}{\sqrt{24-1}}} \\
& =\frac{-14,79}{\left(\frac{4,208}{\sqrt{23}}\right)} \\
& =\frac{-14,79}{\left(\frac{4,208}{4,796}\right)} \\
& =\frac{-14,79}{0,877}
\end{aligned}
$$

$t_{o}=-13,91$

Memberi interprestasi

terhadap harga to

a. Mencari df

$$
\begin{aligned}
& \mathrm{Df}=\mathrm{N}-1 \\
& \mathrm{Df}=24-1=23
\end{aligned}
$$

b. Berkonsultasi pada tabel nilai"t". Dengan $\mathrm{df}=23$ di peroleh harga kritik "t" atau tabel sebagai berikut:

Pada taraf signifikan 5\% =2,07

Pada taraf signifikan $1 \%=2,81$

c. Membandingkan harga to dengan tabeldengan ketentuan:

1) Bila harga tosama dengan atau lebih besar dari tabel maka hipotesis nol $\left(\mathrm{H}_{\mathrm{o}}\right)$ ditolak yang berarti ada perbedaan yang dignifikan.

2) Bila harga to lebih kecil dari harga tabel maka hipotesis nol 
$\left(\mathrm{H}_{\circ}\right)$ diterima yang berarti tidak ada perbedaan yang signifikan.

Dengan to aktivitas belajar siswa sebesar $-10,42$ dan tohasil belajar siswa sebesar $-13,91$ berarti lebih besar dari tabel pada taraf signifikan $5 \%(2,07)$ maupun pada taraf signifikan $1 \%(2,81)$ atau dapat dituliskan $(2,07<13,91$ $>$ 2,81).Tabel harga "t" selengkapnya ada pada lampiran7.

\section{E. KESIMPULAN}

Setelah melaui pemaparan pembahasan sebagaimana penulis paparkan di atas, maka dapat penulis simpulkan sebagai berikut:

1. Penerapan model pembelajaran Time Token Arends dapat meningkatkan aktivitas belajar siswa kelas IX pada mata pelajaran Sejarah Kebudayaan Islam di MTs PP. YAPITA Tambusai Kabupaten Rokan Hulu, dari $53,13 \%$ pada sebelum tindakan menjadi $71,88 \%$ pada siklus I dan akhirnya mencapai $87,50 \%$ pada siklus II.

2. Penerapan model pembelajaran Time Token Arends dapat
Berdasarkan data penelitian baik sebelum dan sesudah dilakukan tindakan menunjukkan bahwa penerapan model pembelajaran time token arends dapat meningkatkan aktivitas dan hasil belajar siswa kelas IX pada mata pelajaran Sejarah Kebudayaan Islam di MTs. PP. YAPITA Tambusai Kabupaten Rokan Hulu.

meningkatkan hasil belajar siswa kelas IX pada mata pelajaran Sejarah Kebudayaan Islam di MTs PP. YAPITA Tambusai Kabupaten Rokan Hulu, dimana pada sebelum tindakan diperoleh jumlah total nilai sebesar 1580 dengan ratarata sebesar 65,83 dan ketuntasan kelas mencapai $37,50 \%$, pada siklus I diperoleh jumlah total nilai 1730 dengan rata-rata sebesar 72,08 dan ketuntasan kelas mencapai $70,83 \%$, selanjutnya pada siklus II diperoleh jumlah total nilai sebesar 1935 dengan rata-rata sebesar 80,63dan ketuntasan kelas mencapai $100 \%$. 


\section{DAFTAR PUSTAKA}

Abdurrahman, Mulyono. (1999). Pendidikan Bagi Anak Berkesulitan Belajar, Jakarta: Rineka Cipta.

Ali, H.,M. (2008). Guru Dalam Proses Belajar Mengajar, Bandung: Sinar Baru Algesindo.

AM, Sardiman. (2008). Interaksi dan Motivasi Belajar Mengajar, Jakarta: PT. Raja Grafindo Persada.

Anwar, Desi. (2004). Kamus Lengkap Bahasa Inggris, Surabaya: Amelia

Budiningsih, C. Asri. (2005). Belajar dan Pembelajaran, Jakarta: Rineka Cipta

Cahya Alviandri, Langkah-Langkah Model Pembelajaran Kooperatif, (Online) http: kuliahpgsd.

blogspot.com/2012/01/

langkah-langkah-model-

pembelajaran.html, diakses pada tanggal 05 Desember 2015.

Departemen Pendidikan Nasional. (2005). Kamus Besar Bahasa Indonesia, Jakarta: Balai Pustaka.

Dimyati., Mudjiono. (2006). Belajar dan Pembelajaran, Jakarta: Rineka Cipta.

Hartono. (2008). Statistik Untuk Penelitian, Yogyakarta:

Pustaka Pelajar.

Iriyanti, Ana Ivar. (2012). Penerapan Metode Pembelajaran Time Token Arend Pada Siswa Kelas VIII A SMP N 1 Prambanan Dalam Upaya Meningkatkan Keaktifan dan Prestasi Belajar pendidikan Kewarganegaraan, Skripsi: Prodi Pendidikan
Kewarganegaraan dan Hukum

Fakultas IImu sosial Universitas Negeri Yogyakarta. Kementrian Agama RI. (2012). AlQur'an dan Terjemahnya, Jakarta: Dirjen Bimas Islam.

Kunandar. (2008). Langkah Mudah Penelitian Tindakan Kelas Sebagai Pengembangan Profesi Guru, Jakarta: PT. RajaGrafindo Persada. (2010). Guru Profesional, Jakarta: PT. RajaGrafindo Persada.

Lampiran PERMENAG RI No. 2 Tahun 2008

Margono, S. (2005). Metode Penelitian Pendidikan, Jakarta: Rineka Cipta.

Mas'ud. (2008). Sejarah Kebudayaan Islam untuk Siswa Kelas IX MTs, Jakarta: Erlangga.

Depdiknas.(2008). Peraturan Menteri Agama RI No. 2 Tahun 2008 tentang Standar Kompetensi Lulusan dan Standar Isi Pendidikan Agama Islam dan Bahasa Arab di Madrasah,

Depdiknas.(2005). PP No. 19 Tahun 2005 tentang Standar Nasional Pendidikan

Purwanto, Ngalim. (2004). Psikologi Pendidikan, Bandung: Remaja Rosdakarya.

Purwanto. (2013). Evaluasi Hasil Belajar, Yogyakarta: Pustaka Pelajar.

Richard I Arend. (2008). Learning to Teach. Terj. Helly Prajitno Soetjipto dan Sri Mulyantini Soetjipto. Yogyakarta: Pustaka Pelajar. 
Rohani, Ahmad. (2008).

FKIP Universitas Sebelas

Pengelolaan Pengajaran, Jakarta: Rineka Cipta.

Rusman. (2012). Model-Model

Pembelajaran

Mengembangkan

Profesionalisme Guru, Jakarta:

Rajawali Press.

Sagala, Syaiful. (2010). Konsep dan Makna Pembelajaran, Bandung: Alfabeta.

Sanjaya, Wina. (2010). Strategi

Pembelajaran Berorientasi

Standar Proses Pendidikan, Jakarta: Kencana.

Sanjaya, Wina. (2011). Penelitian Tindakan Kelas, Jakarta: Kencana Prenada Media Group.

Shoimin, Aris. (2014). 68 Model Pembelajaran Inovatif dalam Kurikulum 2013, Yogyakarta: Ar-Ruzz Media

Slameto. (2010). Belajar dan Faktor-faktor yang Mempengaruhi, (Jakarta: Rineka Cipta.

Sudjana, Nana. (2002). DasarDasar Proses Belajar Mengajar, (Bandung: Sinar Baru Algesindo.

Suprijono, Agus. (2013). Cooperative Learning Teori dan Aplikasi Paikem, Yogyakarta: Pustaka Pelajar.

Syah, Muhibbin. (2008). Psikologi Belajar, Jakarta: PT. RajaGrafindo Persada.

Trianto. (2010). Mendesain Model Pembelajaran InovatifProgresif, Jakarta: Kencana.

Wahyuni, Tri. (2013). Penerapan Model Pembelajaran Kooperatif Tipe Time Token Arends Untuk Meningkatkan Pemahaman Tentang Globalisasi, Skripsi: PGSD 